\title{
Serial superficial digital flexor tendon biopsies for diagnosing and monitoring collagenase-induced tendonitis in horses ${ }^{1}$
}

\author{
José C. de Lacerda Neto ${ }^{2 *}$, Juliana M.R. de Freitas ${ }^{2}$, Franco M. Poggiani ${ }^{2}$, Deborah P.M. Dias ${ }^{2}$, \\ Kamila Gravena ${ }^{2}$, Nara S. Bernardi² ${ }^{2}$ Gesiane Ribeiro ${ }^{3}$ and Vívian Palmeira-Borges ${ }^{4}$
}

\begin{abstract}
Lacerda Neto J.C., Freitas J.M.R., Poggiani F.M., Dias D.P.M., Gravena K., Bernardi N.S., Ribeiro G. \& Palmeira-Borges V. 2013. Serial superficial digital flexor tendon biopsies for diagnosing and monitoring collagenase-induced tendonitis in horses. Pesquisa Veterinária Brasileira 33(6):710-718. Departamento de Clínica e Cirurgia Veterinária, Faculdade de Ciências Agrárias e Veterinárias, Universidade Estadual Paulista, Via de Acesso Prof. Paulo Donato Castellane s/n, Jaboticabal, SP 14884-900, Brazil. E-mail: jlacerda@fcav.unesp.br

The purpose of this investigation was to demonstrate the feasibility of a biopsy technique by performing serial evaluations of tissue samples of the forelimb superficial digital flexor tendon (SDFT) in healthy horses and in horses subjected to superficial digital flexor tendonitis induction. Eight adult horses were evaluated in two different phases $(\mathrm{P})$, control (P1) and tendonitis-induced (P2). At P1, the horses were subjected to five SDFT biopsies of the left forelimb, with 24 hours (h) of interval. Clinical and ultrasonographic (US) examinations were performed immediately before the tendonitis induction, 24 and $48 \mathrm{~h}$ after the procedure. The biopsied tendon tissues were analyzed through histology. P2 evaluations were carried out three months later, when the same horses were subjected to tendonitis induction by injection of bacterial collagenase into the right forelimb SDFT. P2 clinical and US evaluations, and SDFT biopsies were performed before, and after injury induction at the following time intervals: after 24, 48, 72 and $96 \mathrm{~h}$, and after 15, 30, 60, 90, 120 and 150 days. The biopsy technique has proven to be easy and quick to perform and yielded good tendon samples for histological evaluation. At P1 the horses did not show signs of localised inflammation, pain or lameness, neither SDFT US alterations after biopsies, showing that the biopsy procedure per se did not risk tendon integrity. Therefore, this procedure is feasible for routine tendon histological evaluations. The P2 findings demonstrate a relation between the US and histology evaluations concerning induced tendonitis evolution. However, the clinical signs of tendonitis poorly reflected the microscopic tissue condition, indicating that clinical presentation is not a reliable parameter for monitoring injury development. The presented method of biopsying SDFT tissue in horses enables the serial collection of material for histological analysis causing no clinical signs and tendon damage seen by US images. Therefore, this technique allows tendonitis to be monitored and can be considered an excellent tool in protocols for evaluating SDFT injury.
\end{abstract}

INDEX TERMS: Tendonitis, biopsy, collagenase, histology, equidae.

\footnotetext{
${ }^{1}$ Received on January 15, 2013.

Accepted for publication on April 15, 2013.

${ }^{2}$ Departamento de Clínica e Cirurgia Veterinária, Faculdade de Ciências Agrárias e Veterinárias (FCAV), Universidade Estadual Paulista (Unesp), Via de Acesso Prof. Paulo Donato Castellane s/n, Jaboticabal, SP 14884900, Brazil. *Corrresponding author: jlacerda@fcav.unesp.br

${ }^{3}$ Faculdades Metropolitanas Unidas (FMU), Rua Ministro Nelson Hungria 541, São Paulo, SP 05690-050, Brazil.

${ }^{4}$ Ministério da Agricultura, Pecuária e Abastecimento (MAPA), Esplanada dos Ministérios Bloco D, Brasília, DF 70043-900, Brazil.
}

RESUMO.- [Biópsias seriadas do tendão flexor digital superficial para o diagnóstico e monitoração da tendinite induzida por colagenase em equinos.] Objetivou-se demonstrar a viabilidade de uma técnica de biópsia na realização de avaliações sequenciais de amostras de tecido do tendão flexor digital superficial (TFDS) do membro torácico, em equinos hígidos e em equinos submetidos à indução de tendinite do TFDS. Oito equinos adultos foram avaliados em duas fases (F) diferentes, controle (F1) e apresentando 
tendinite induzida (F2). Na F1, os equinos foram submetidos a cinco biópsias do TFDS do membro torácico esquerdo, com 24 horas (h) de intervalo entre as mesmas. Avaliações clínicas e ultrassonográficas (US) foram realizadas imediatamente antes e, 24 e $48 \mathrm{~h}$ após cada procedimento. 0 tecido tendíneo coletado por biópsia foi analisado histologicamente. A F2 ocorreu três meses depois, quando os mesmos equinos foram submetidos à indução de tendinite do TFDS do membro torácico direito por injeção intratendínea de colagenase. Na P2, Avaliações clínicas e US foram realizadas antes da indução da tendinite e após a mesma nos seguintes momentos: 24, 48, 72 e 96 h depois e, 15, 30, 60, 90, 120 e 150 dias depois. A técnica de biópsia se demonstrou ser de fácil e rápida realização, fornecendo fragmentos de tecido tendíneo adequados para a realização de histologia. Na F1, os equinos não demonstraram sinais de inflamação local, dor ou claudicação, bem como não apresentaram alterações na avaliação US do TFDS após as biópsias, demonstrando que o dano físico ao tendão provocado pela biópsia não compromete sua integridade. Assim, o procedimento pode ser utilizado rotineiramente para avaliações histológicas do tecido tendíneo. Na F2, observou-se uma relação entre os achados US e histológicos no que se refere à evolução da tendinite induzida. Entretanto, observou-se que os sinais clínicos da tendinite não acompanham a condição microscópica do tecido, o que indica que a apresentação clínica não pode ser utilizada como parâmetro para a monitoração da evolução da enfermidade. A técnica de biópsia apresentada para colheita de tecido do TFDS em equinos, permite a obtenção de tecido para avaliação histológica seriada sem provocar sinais clínicos e alterações ultrassonográficas que indiquem dano tecidual. Assim, a técnica permite a monitoração da tendinite e pode ser considerada uma excelente ferramenta na avaliação de injúrias do TFDS.

TERMOS DE INDEXAÇÃO: Tendinite, biópsia, colagenase, histologia, equídeos.

\section{INTRODUCTION}

Tendon injury is one of the most common causes of wastage in the performance horse, most commonly occurring to the superficial digital flexor tendon (SDFT) (Rantanen et al. 1985, Goodship et al. 1994, Gillis 1997, Patterson-Kane et al. 1998, Dahlgren et al. 2001, Thorpe et al. 2010). Tendonitis usually leads to lameness followed by a long layoff period for tendon healing and rehabilitation, resulting in great financial loss in equestrian competitive sports (Gillis 2004, Marxen et al. 2004).

Tendonitis in the horse is primarily associated with muscular fatigue, inadequate vascular supply and collagen fiber ruptures due to overstrain and overheating of the tendon during exercise (Kraus-Hansen et al. 1992, Watkins 1992, Patterson-Kane et al. 1997, Patterson-Kane et al. 1998, Cherdchutham et al. 2001, Yamasaki et al. 2001, Oikawa \& Kasashima 2002). The SDFT resistance can easily be exceeded if the horse is fatigued or moves in an uncoordinated manner, which can lead to partial or total rupture (Batson et al. 2003). In addition, factors related to poor limb conformation, inadequate trimming and shoeing, excessive weight, and inappropriate exercise performance can also contribute to tendon injury (Gillis 1997, Reef 1998).

Tendonitis treatment in horses is almost always frustrating due to the long tendon repairing time. Tendon fiber composition, structure and function are never fully restored after the injury, increasing the risk of re-injuries and compromising the horse's athletic life (Goodship 1993, Dowling et al. 2000, Richardson et al. 2007). A controlled exercise rehabilitation program during the recovery period is necessary to improve elasticity and alignment of tendon fibers (Gillis 1997).

Investigations of the SDFT ultrastructure have been performed to increase our knowledge of tendonitis etiopathogenesis, leading to the development of more efficient prevention and treatment methods (Alves et al. 2001). Ultrasound (US) examination is the best way for routine assessment of tendon lesion degree and evolution and may provide a good prognosis (Reef 1998, Alves et al. 2001, Oikawa \& Kasashima 2002). Three-dimensional and two-dimensional US were shown to be repeatable techniques for measuring the volume of a tendon lesion (Ferrari et al. 2006). It is known that tendonitis clinical signs are not always correlated to tendon fiber injury (Genovese et al. 1986). Likewise, even using a high-resolution probe, US limitations include the inability to see the tendon tissue details and correlate abnormal findings with the mechanical properties, especially at later phases of repair (Denoix 1994, Smith et al. 1994, Dowling et al. 2000, Van Schie et al. 2003).

Biopsy techniques have been investigated for the purpose of providing accurate evaluation and monitoring of tendon injuries. Tissue sample analysis has the ability to guide tendonitis treatment, to aid in deciding for adequate rehabilitation programs and to specify the optimum time to resume exercising, avoiding lesion aggravation. However, the biopsy must be easy to perform with as little trauma as possible. Buck et al. (2002) first described the use of biopsy equipment, allowing for electron microscopy evaluations of tendon fibrils in horses. The study evaluated core biopsies of 12 healthy flexor tendons and 40 flexor tendons at different stages of tendonitis, demonstrating that the typical fibril organisation in the different phases of healing could be shown in the biopsy tissue. Thus, the purpose of this investigation was to demonstrate the feasibility of a biopsy technique by performing serial evaluations of the forelimb SDFT in healthy horses and in horses subjected to superficial digital flexor tendonitis induction.

\section{MATERIALS AND METHODS ${ }^{5}$}

\section{Study design}

Eight adult Arabian horses, seven females and one male, with a median age of 5 years and a median body weight of $330 \mathrm{~kg}$, were included in this study. All horses were considered healthy upon general physical examination and specific examination of the musculoskeletal system. The horses presented normal forelimb

\footnotetext{
${ }^{5}$ The study received ethical approval by the Animal Ethics Committee of FCAV/Unesp (Protocol \#030926-04).
} 
SDFT upon inspection, and in a sonographic view, the horses exhibited a normal echogenic aspect of the tendon tissue. The horses were examined in two different phases (P), control (P1) and tendonitis-induced (P2), including clinical evaluation and US examinations examination of the SDFT. Macroscopic and histological evaluations of tendon tissue samples collected through biopsies were also performed.

\section{Control phase (P1)}

At P1, the horses were subjected to five SDFT biopsies of the left forelimb, with 24 hours (h) of interval, and clinical and US examinations were performed immediately before the tendonitis induction, 24 and $48 \mathrm{~h}$ after the procedure, aiming to evaluate the recovery period after biopsies performed in series. Clinical evaluations included heart rate, respiratory rate, rectal temperature and mucous membranes color; degree of lameness determined as absent, mild, moderate or severe; local biopsy site sensitivity through palpation determined as absent, mild, moderate or severe; local biopsy site swelling, determined as absent, mild, moderate or severe; local biopsy site temperature, measured with an infrared thermometer (Infrared thermometer SK-8700, Sato Keiryoki MFG.), with emissivity set at 0.95 and positioned $10 \mathrm{~cm}$ from the skin surface.

The US examinations to evaluate the left forelimb SDFT were performed with the horses standing, unsedated and restrained by an experienced handler. A digital US system (Pie Medical Scanner 200 VET) with a 7.5-MHz linear transducer was used. Hair was clipped over the palmar aspect of the middle metacarpal region. A silicon pad and coupling gel were used to ensure adequate contact between the skin and transducer. Both longitudinal and transversal scans were obtained. The echogenicity was determined based on a scale of 1 to 4, as suggested by Genovese et al. (1986) and Reef (1998). The assessment of changes in fiber alignment, which was based on the linear arrangement of the echoes in the longitudinal images, was graduated on a scale of 0 to 3 (Reef 1998).

The P1 left forelimb SDFT biopsies were carried out with horses standing, unsedated and twitch-restrained. The hair over the biopsies site had already been clipped for US evaluation. Perineural nerve blocks of the medial and lateral nerves (palmar metacarpal and palmar digital) at the proximal metacarpal third of the left forelimb were carried out by infiltration of $3 \mathrm{~mL}$ of $2 \%$ lidocaine chloride without vasoconstrictor (Xylestesin 2\%, Cristália) around each nerve. The site was scrubbed with $1 \%$ povidone-iodine solution and rinsed with $0.9 \%$ sodium chloride solution. After sterile preparation of the skin above the tendon, the SDFT tissue sample was collected by an automatic biopsy system (Pro-MagTM Ultra Automatic Biopsy System, Angiotech) connected to a $0.9-\mathrm{mm}$ diameter biopsy needle (Pro-MagTM Biopsy Needle, Angiotech). The left forelimb was lifted and flexed at carpal joint. The biopsy needle, already set in the equipment, was inserted 2 $\mathrm{mm}$ into the skin at a 40 to 50 degree angle from the palmar limb surface (Fig.1). The equipment was fired by pushing in on the front trigger button propelling the needle forward into the tendon obtaining the biopsy sample. The needle was removed from tendon, the specimen was exposed and withdrawn. The same procedure was carried out for the five biopsies, which were all made within an extension of $5 \mathrm{~cm}$ at the middle third of the SDFT.

Tissue samples were immediately placed into aluminum recipients and a tissue freezing medium was applied. Tissue specimens were post-fixed in $\mathrm{n}$-hexane solution at $-14^{\circ} \mathrm{C}$. Longitudinal 5- to 7- $\mu \mathrm{m}$ tissue sections were obtained using a micrometer cryostat. The sections were deposited onto slides, stained with hematoxylin and eosin (H\&E), and were histologically evaluated by optical microscopy. During the first $48 \mathrm{~h}$ after the procedure,

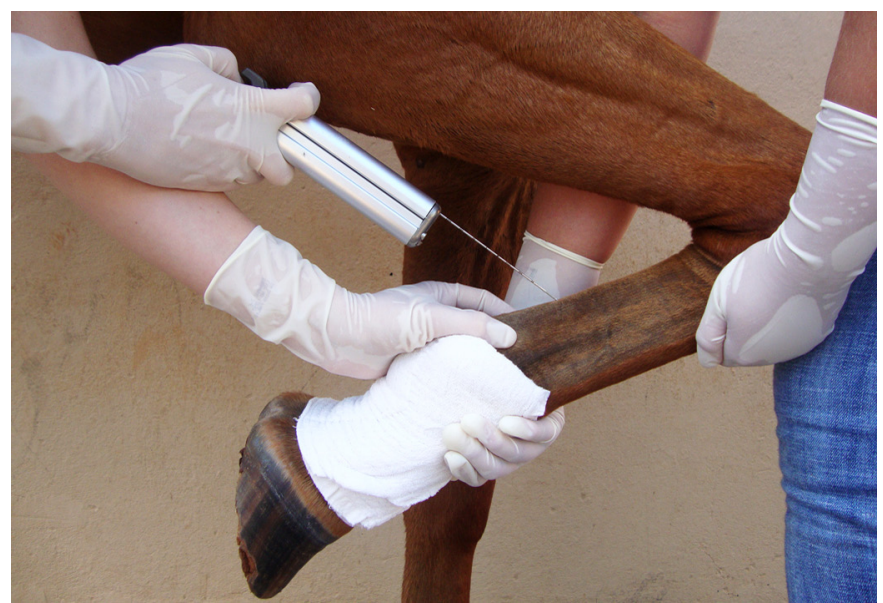

Fig.1. Biopsy device with needle placed on the skin, immediately prior to superficial digital flexor tendon tissue collection.

the left forelimb was wrapped with a sterile bandage from the proximal metacarpal region to the distal metacarpophalangeal joint and the horses were confined in stalls.

\section{Tendonitis-induced phase (P2)}

P2 evaluations were carried out three months after the first biopsies, when the same horses were subjected to tendonitis induction by injection of bacterial collagenase into the right forelimb SDFT. Food, but not water, was withheld for 12 hours before tendonitis induction. The tendonitis induction site was previously determined at the middle point of the right forelimb SDFT, located approximately 10-12 $\mathrm{cm}$ from the distal margin of the accessory carpal bone. At this point, a landmark was outlined with a marking pen after clipping the area. The distance from the skin to the SDFT core was assessed through US view to determine needle length introduction.

The horses were restrained in stocks, and sedated with 0.1 $\mathrm{mg} / \mathrm{kg}$ IV acepromazine (Acepran 1\%, Univet) and pethidine chloride (Petinan, BioChimico, Roche) at $2.0 \mathrm{mg} / \mathrm{kg}$ IM. Perineural nerve blocks of the medial and lateral nerves (palmar metacarpal and palmar digital) at the proximal metacarpal third of the right forelimb were carried out by infiltration of $3 \mathrm{~mL}$ of $2 \%$ lidocaine chloride without vasoconstrictor around each nerve. The tendonitis induction site was scrubbed with $1 \%$ povidone-iodine solution and rinsed with $0.9 \%$ sodium chloride solution. After sterile preparation of the skin above the right SDFT, a $21 \mathrm{G} 1 \frac{1}{2} 2$ in. (3.81 $\mathrm{cm}$ ) hypodermic needle was inserted through the skin at the landmark, reaching the central region of the SDFT and $1 \mathrm{ml}$ of bacterial collagenase solution (Collagenase from Clostridium histolyticum C0130, Sigma-Aldrich) (2.5 mg/ml) was injected. The needle was removed and a sterile bandage was applied from the proximal metacarpal region to the metacarpophalangeal joint.

P2 clinical and US evaluations, and SDFT biopsies were performed before and after injury induction at the following time intervals: 24, 48, 72 and 96 h, and after 15, 30, 60, 90, 120 and 150 days. The horses were confined in stalls for 60 days from lesion induction and then were maintained in paddocks for up to 150 days (end of evaluation period). P2 samples were collected from areas previously determined by US guidance to reach the exact injured area. At this point, a landmark was outlined with a marking pen and the biopsy was performed as described for P1. The developed lesions were sufficiently wide to allow serial sampling from different points along the injured SDFT. The consistency of the tissue was characterised as firm, soft or gelatinous. Each fragment was also analysed for vascularisation and cellularity. The extent of 
parallelism and retraction of the collagen fibers was classified as present, partial or absent.

\section{Statistical analysis}

Clinical and US observations were converted to scores to be compared, and were analysed by application of the Kruskal-Wallis test. Results of $\mathrm{P}<0.05$ were considered as significant differences. The different scores were represented as letters, with the letter "a" representing the most severe condition, proportionally followed by letters "b, c, d and e".

\section{RESULTS}

\section{Clinical findings}

At P1 the horses did not show signs of localised inflammation, pain or lameness. The local biopsy site temperature remained unchanged. Clinical evaluation of P2 horses confirmed maximal swelling and lameness $24 \mathrm{~h}$ after tendonitis induction. Differences $(\mathrm{P}<0.05)$ were observed comparing clinical findings at P1 and initial P2 evaluations (Table 1). Swelling decreased by day 15 but persisted until day 150 . The degree of lameness also decreased by day 15 , persisted at a lower level until day 30 , decreased further on day 60 , and persisted at this level until the end of the evaluation period (day 150). Tendon sensitivity by palpation reached a maximum value $24 \mathrm{~h}$ after tendonitis induction and then decreased $96 \mathrm{~h}$ after the procedure. Sensitivity decreased between day 15 and day 60, and then remained unchanged until day 150. Localised temperature increased $24 \mathrm{~h}$ after tendonitis induction and decreased on day 30 , increased again on day 60, decreased on day 90 and then remained unchanged until day 150.

The most marked changes in clinical parameters of $\mathrm{P} 2$ subjects were observed within the first $24 \mathrm{~h}$ after tendonitis induction. All horses were lame from the first evaluation until the 15th day, but lameness disappeared by the 60th day. Localised swelling and sensitivity to palpation increased within the first $96 \mathrm{~h}$ after induction and then decreased from the 15th day to the end of evaluations and was never observed as normal. Localised temperature re- sults were similar to those for swelling and sensitivity, increasing after induction and continuing until the 15th day. However, the following evaluations showed oscillations in the results.

\section{Ultrasonographic findings}

Differences $(\mathrm{P}<0.05)$ were observed comparing US findings at P1 and initial P2 evaluations (Table 1). At P1 the horses did not present SDFT US alterations. However, at P2 transverse and longitudinal ultrasonographic images showed tendon lesions of variable size, shape and position, from hypo to anechoic and with loss of the linear pattern of fibers. The lesions were generally located in the core of the tendon. In the first hours after tendonitis induction, the ultrasonographic evaluation showed circumspect hypoechoic areas and parallelism loss in the fibers. The maximum alteration of ultrasound parameters was observed $96 \mathrm{~h}$ after induction. Echogenicity of the lesions regressed by a statistically significant amount after the 60th day, and degree of tendon fiber parallelism improved after the 150th day.

\section{Biopsy technique}

The biopsy technique has proven to be easy and quick to perform and yielded good tendon samples for histological evaluation. Despite their small size and fragility, the biopsy samples obtained were sufficient to evaluate the tendon tissue, providing information about tendonitis evolution. All collection sites were determined with the guidance of previous ultrasounds. Due to the reduced extension of the lesions for the fragments collected 24 or $48 \mathrm{~h}$ after tendonitis induction (P2), the exact locations for tissue extraction proved to be more difficult to determine, comparing to following tissue collections ( $96 \mathrm{~h}$ to 150 days). However, the procedure became more accurate as the surgeon became familiar with and practiced the technique.

\section{Tendon tissue macroscopic evaluation}

Macroscopic evaluations of biopsy samples were performed immediately after collection. Concerning the qua-

Table 1. Clinical and ultrasonographic evaluations, carried out at different time intervals, in healthy horses subjected to serial superficial digital flexor tendon (SDFT) biopsies (P1) and in horses subjected to tendonitis induction and serial SDFT biopsies (P2). Data were analysed by Kruskal-Wallis non-parametric test $(P<0.05)$. Different scores are indicated by letters, with the letter "a" indicating the highest value, proportionally followed by the letters "b, c, $d$ and $e$ "

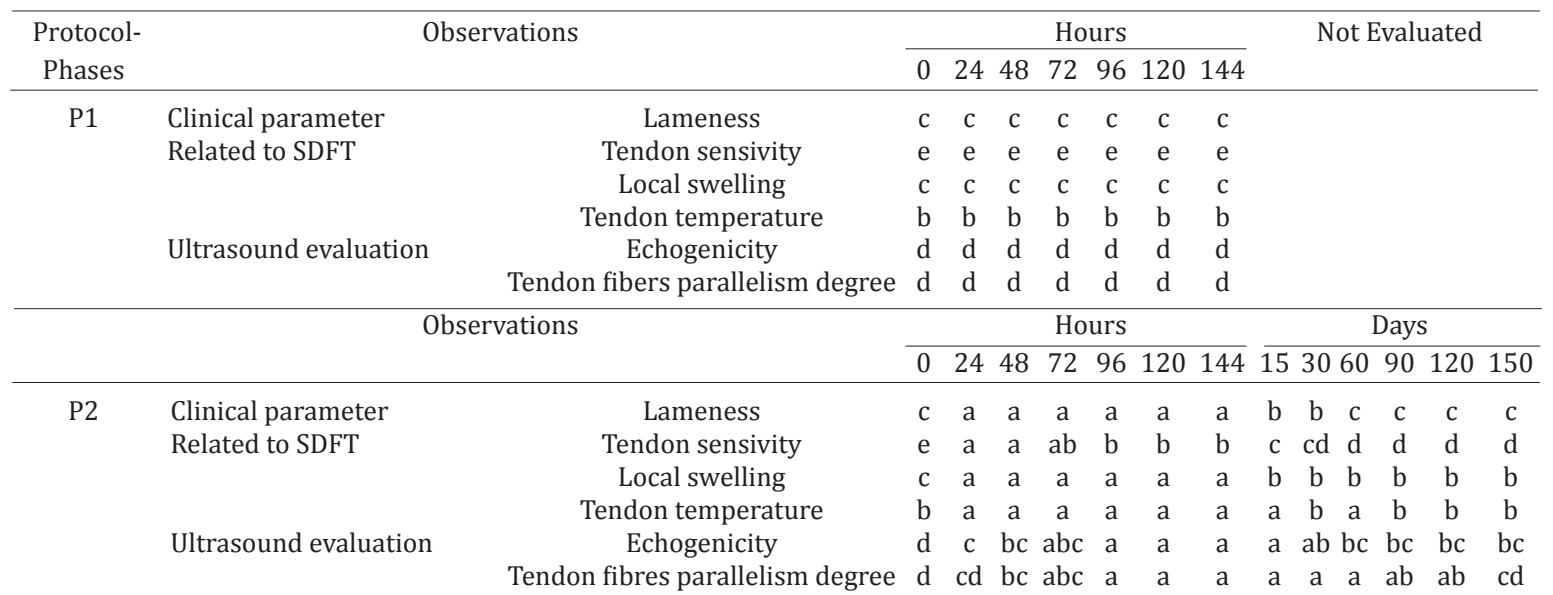




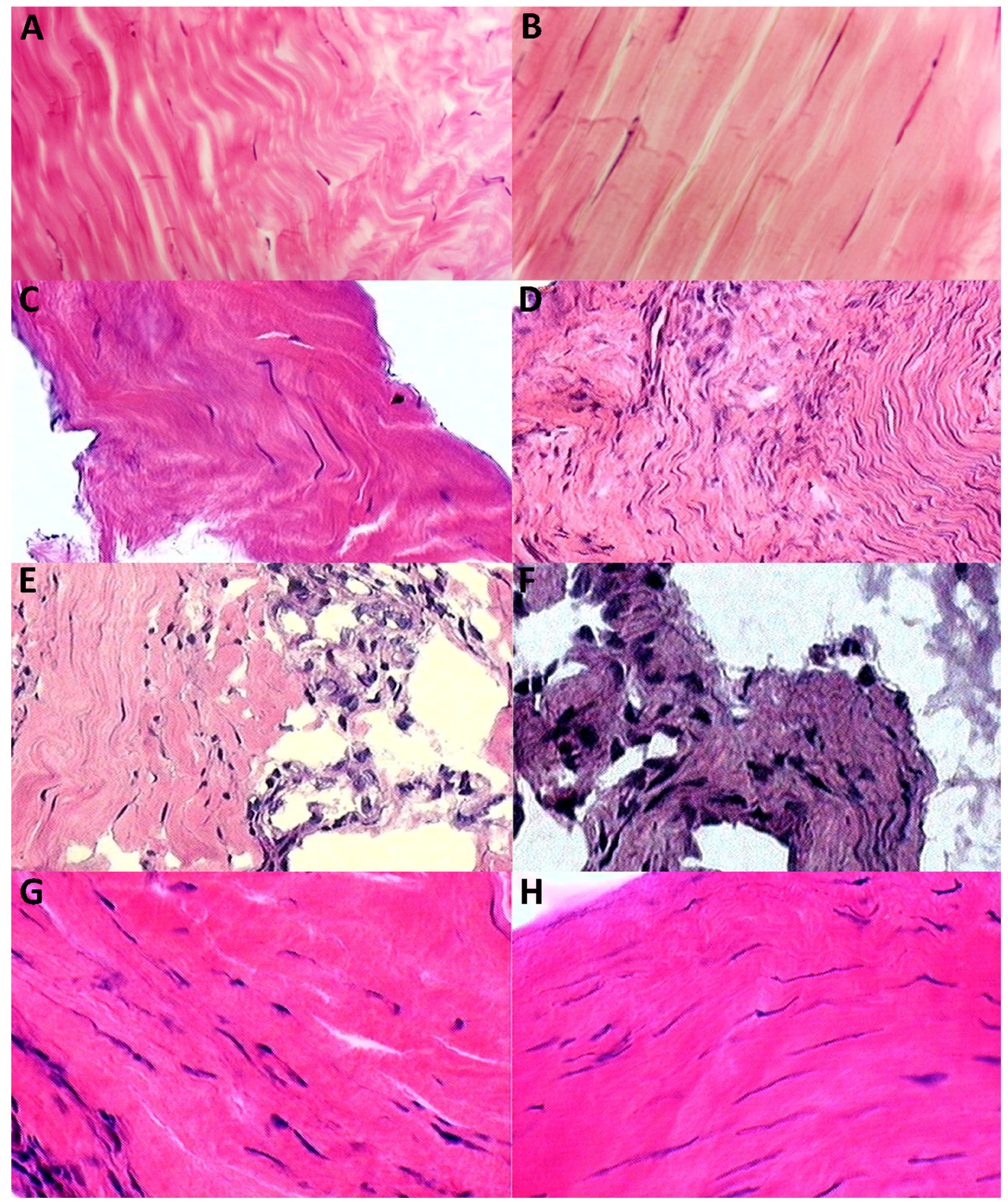

Fig.2. Photomicrographs of superficial digital flexor tendon (SDFT) samples of horses obtained at different time intervals at P1 (control) and P2 (tendonitis-induced) (H\&E stain). (A) Longitudinal section of a normal SDFT sample obtained at P1 (Obj. 40x). (B) Longitudinal section of a normal SDFT sample obtained at P1 (Obj.100x). (C) Longitudinal section of an SDFT $48 \mathrm{~h}$ after tendonitis induction (P2), showing tenuous cellularity and thin endotenon (Obj.40x). (D) Longitudinal section of an SDFT $72 \mathrm{~h}$ after tendonitis induction (P2), showing many inflammatory cells (Obj.10x). (E) Longitudinal section of an SDFT 15 days after tendonitis induction (P2), showing misalignment of tendon fibres and increased cellularity (Obj.20x). (F) Longitudinal section of an SDFT 60 days after tendonitis induction (P2), showing inflammatory cells (Obj.40x). (G). Longitudinal section of an SDFT 120 days after tendonitis induction (P2), showing increased cellularity and hypertrophied fibroblast nuclei (Obj.40x). (H) Longitudinal section of an SDFT 150 days after tendonitis induction (P2), showing increased cellularity (Obj.40x). 
lity of the fragments, P1 specimens were stiff but fragile with manipulation. The macroscopic aspects of P2 fragments were gelatinous and friable, suggesting the presence of edema in all evaluations except those completed prior to tendonitis induction. The fragments were brittle and easily destroyed during manipulation possibly due to the presence of inflammation. However, all obtained fragments were sufficient to perform the histological evaluations as proposed. Only two horses exhibited better consistency of fragments by the $30^{\text {th }}$ day. For the individual evaluations, the most altered fragments belonged to horses presenting the most severe lesions, as shown by ultrasound.

\section{Histology}

Hematoxylin and eosin staining was used to determine the SDFT integrity and provided satisfactory analyses. Histological evaluation of P1 tissues revealed normal SDFT tissue with fusiform-shaped fibroblasts containing long nuclei and little cytoplasm, located parallel to the tendon fibers (Fig.2A and Fig.2B). Some samples, however, presented disorganised collagen fibers.

In the histological evaluations of P2 specimens at 24 and $48 \mathrm{~h}$ after tendonitis induction, the tissues of four horses contained tenuous cellularity and thin endotendon (Fig.2C); furthermore, in two horses, the tissues had up to 2 mononuclear inflammatory cells per optic microscopy field (40x) and small necrosis foci. After $72 \mathrm{~h}$, all horse tissues displayed mononuclear inflammatory cells (Fig.2D), but at $96 \mathrm{~h}$, only one horse showed abnormal fibroblasts and a small haemorrhagic area. Fifteen days after tendonitis induction, all the horses demonstrated tendon fiber misalignment and increased cellularity (Fig.2E), identified by the presence of mononuclear inflammatory cells and active fibroblasts. Fibroblast morphology changed from a fusiform (inactive) to round (active) shape. The tissues of two horses exhibited neovascularisation on day 15.

Thirty days after tendonitis induction, the tissues of two horses presented mononuclear and polymorphonuclear cells, and one tissue sample contained macrophages. On day 60 , all the histological evaluations revealed decreased cellularity, but with the presence of some inflammatory cells (Fig.2F), and the tissues of three horses displayed neovascularisation. In the tissues of two horses, polymorphonuclear cells were present, and no macrophages were observed. Collagen fibers were misaligned in the presence of inflammatory cells when compared with the other sites. Biopsy fragments collected 90,120 or 150 days after induction remained unchanged from those collected on day 60. Histology at 120 days after induction showed increased cellularity and hypertrophied fibroblast nuclei (Fig.2G), and after 150 days induction, histology indicated increased cellularity (Fig.2H).

\section{DISCUSSION}

\section{Clinical findings}

The absence of SDFT inflammation, pain or lameness in P1, when five serial biopsies with $24 \mathrm{~h}$ of interval were carried out, contrast to P2 horses that showed these signs at the same period. Therefore, the signs were associated to tendonitis induction demonstrating that the biopsy proce- dure, even performed in series, does not risk tendon integrity and the development of clinical signs.

The tendonitis induction technique had been standardised previously by other authors (Silver et al. 1983, Williams et al. 1984, Spurlock et al. 1989, Gaughan et al. 1991, Foland et al. 1992, Keg et al. 1992, Gaughan et al. 1995, Machado et al. 2000, Alves et al. 2002, Marxen et al. 2003, Marxen et al. 2004, Fernandes et al. 2003, Barreira et al. 2008, Maia et al. 2009, Yamada et al. 2009) and successfully produced lesions located in the SDFT core region, as described by Webbon 1977. According to Gillis 1997, humans reported tendonitis as painful for 3 to 8 weeks after injury, when properly rested. The same was observed in the horses of this study at P2, all of which demonstrated an absence of lameness 60 days after injury. Therefore, only the ultrasonographic evaluation is reliable for determining the status of the tendon lesions because clinical signs usually disappear before complete tendon fiber repair (Denoix 1994).

The P2 horses exhibited localised swelling, heat and pain over the SDFT from the first hours after induction, indicating inflammation, as described for the clinical occurrence of tendonitis (Dahlgren 2007). The clinical findings after tendonitis induction were in accordance with Marxen et al. (2004). However, Silver et al. (1983) and Williams et al. (1984) observed remission of localised sensitivity and heat after 15 days from induction, in contrast to the observations from the present study, whereas local swelling and sensitivity to palpation were never observed as normal. The oscillations observed in tendon temperature were most likely due to the different seasons in which the evaluations were conducted and may have included environmental temperature variations that influenced the localised measurements.

\section{Ultrasonographic findings}

The images of normal SDFT tissues observed in control phase (P1), showing a fine arrangement of dots, homogeneous textures and linear fiber patterns, were in accordance to normal tendon tissue US presentation (Dyson 1992, Pasin et al. 2001, Rantanen 2008). At P2, induced tendonitis evolution was observed through US view as anechoic and hypoechoic areas matching the points of hemorrhage, edema and tendon fiber rupture. These findings may be explained by the inflammatory exudate macrophages that continuously release protease and collagenase, which exert enzymatic activity (Genovese et al. 1986, Crass et al. 1992, Foland et al. 1992, Reef 1998, Marxen et al. 2004).

The normal US tendon images in P1 were in accordance to normal clinical findings, showing that US tendon pattern changes observed in P2 were related also to tendonitis induction, confirming once again the safety of serial biopsies method. The ultrasound evaluation carried out 150 days after induction revealed a gain in longitudinal orientation of fibers reflecting the maturation phase of the tendon tissue, as described by Jann \& Stashak (2008). This aspect was in accordance with the tendon healing 150 days after injury, whereas its known that despite collagen concentration and density were re-established after 6 months, the tendon fi- 
ber alignment and complete tissue restoration occurred only after one year from the onset of the disease (Van Schie et al. 2003).

\section{Biopsy technique}

Webbon et al. (1986) described a tendon biopsy procedure intended as a serial tendonitis diagnostic technique, obtaining fragments from $0.6 \mathrm{~mm} \times 0.1 \mathrm{~mm}$ to $0.9 \mathrm{~mm} \times$ $0.2 \mathrm{~mm}$ using a surgical procedure. Maia et al. (2009) also performed SDFT biopsies with a surgical procedure, obtaining a fragment that was $0.8 \mathrm{~cm}^{3}$ in volume for histological evaluation. These two techniques were performed under general anaesthesia, and as described by Maia et al. (2009), a tenorrhaphy was needed to restore the tendons, complicating the outcomes and enabling the collection of only one fragment per limb.

Buck et al. (2002) used a biopsy device, similar to that used in this study, to collect flexor tendon fragments. However, the harvested fragments were longer $(1.6 \mathrm{~cm}$ long), the horses outcome after the procedure were not evaluated and the authors did not perform serial collections. The present study first describes the use of a biopsy device and specific needle to collect tissue samples in a series from horses' SDFT. These procedures have been shown to be technically simple and easy to perform; additionally, they can be accomplished in horses unsedated and do not prejudice tissue integrity, as demonstrated by clinical and US evaluations. The present investigation also describes a biopsy technique that provides convenient, feasible and minimally invasive tendon tissue access, suitable for serial evaluations. However, due to the small size of the fragments (3 $\mathrm{mm} \times 1.5 \mathrm{~mm}$ ), the macroscopic and histological evaluations were limited in few samples.

\section{Tendon tissue macroscopic evaluation}

The macroscopic aspect of tendon tissue obtained through biopsy in P2 were similar to those described by Williams et al. (1984), who observed exudate and hemorrhage at the lesion site $24 \mathrm{~h}$ after induction and gelatinous tissue 30 days later. They were also similar to those described by Buck et al. (2002), who observed a significant difference in texture-values comparing control and tendonitis groups. The altered consistency in tendon tissue samples obtained in the present study could be explained initially due to inflammation, with collagen degeneration and necrosis (24-96 h after injury), and due to immature and disorganised collagen fibers at later phases (15-150 days after injury).

\section{Histology}

Studies have previously demonstrated that H\&E staining enables the cellular characterisation and evaluation of tendon tissues (Maia et al. 2009). Therefore, various parameters of histology were successfully assessed, including cellularity, presence of haemorrhage, necrosis and collagen degeneration. Nevertheless, it was impossible to evaluate the parallelism of fibers due to the small fragment size, indicating a disadvantage of our technique compared with the methods in Maia et al. (2009).
The SDFT tissue aspect observed in P1 samples was in accordance with description already reported for normal tissues (Dahlgren 2007). The observed disorganised collagen fibers in some samples obtained in P1 were probably due to partial retraction of the fragments during sample processing. The absence of increased cellularity until $48 \mathrm{~h}$ after induction in four horses contradicts the clinical findings, as the horses presented swelling, pain and lameness, as well as the US findings, as the horses exhibited a loss of parallelism in the tissue fibers. From $72 \mathrm{~h}$ until the end of evaluation period, the histological findings were in accordance with injury development of cellularity. The increased cellularity found in P2 samples, collected fifteen days after tendonitis induction, was also described in other studies that had evaluated induced tendonitis using collagenase (Foland et al. 1992, Machado et al. 2000, Alves et al. 2002, Maia et al. 2009). The presence of neovascularisation observed fifteen days after tendonitis induction occurs to improve tendon tissue repair after injury (Maia et al. 2009), suggesting a normal healing process of the induced tendonitis in the present study.

In the present study, microscopic findings such as inflammatory cells were evident between 72 and $96 \mathrm{~h}$ after tendonitis induction, and cellularity increased from day 15 , which is consistent with other reports (Silver et al. 1983, Williams et al. 1984, Crass et al. 1992, Marr et al. 1993, Redding et al. 1999). During the initial healing stages after a tendon injury, tissues indicated increased cellularity. $A$ posteriori, the number of cells decreased during the remodelling and maturation phases. A reduction in the number of fibroblasts during the healing process suggests the maturity of the collagen fibers (Redding et al. 1999). As for the specific identification of cells, macrophages were observed 30 days after induction and polymorphonuclear cells after 30 and 60 days. These findings contradict those of Williams et al. (1984) who reported the presence of polymorphonuclear cells within the first $24 \mathrm{~h}$ and macrophages one week after induction.

The present findings demonstrate a correlation between the ultrasound and histology evaluations. However, clinical presentation poorly reflected microscopic tendon condition because lameness was evident in early phases of tendonitis when microscopic lesions were not fully defined. Furthermore, the clinical signs of tendonitis usually decrease before histological resolution, indicating that clinical presentation is not a reliable parameter for monitoring injury development.

\section{CONCLUSIONS}

Based on the results of our study, we conclude that our method of collecting tendon tissues in horses by biopsy enables the serial collection of material for histological analysis.

More importantly, histological analysis demonstrated that the samples did not damage the cells. Considering that no alterations of tissues of the SDFT were found by US in the healthy horses (P1) and that the horses presented no 
signs of lameness, our procedure did not risk tendon integrity.

Thus, these results indicate that the use of this procedure is feasible for routine evaluations. This biopsy technique can be considered an excellent method for obtaining tendon tissues and can be used in protocols for evaluating tendonitis.

Although our tendon biopsy technique has been determined to be feasible overall, further studies that aim to improve tissue fragment collection and processing are needed to improve and verify the safety of this method. The ultimate goal is to develop a reliable serial scheme of tendon structure evaluation to monitor fiber regeneration, allowing for improved patient rehabilitation and an ideal return to athletic activity.

Acknowledgements.- To Fundação de Amparo à Pesquisa do Estado de São Paulo (FAPESP) for financial assistance.

\section{REFERENCES}

Alves A.L.G., Rodrigues M.A.M., Aguiar A.J.A., Thomassian A., Nicoletti J.L.M., Hussni C.A. \& Borges A.S. 2001. Effects of beta-aminopropionitrile fumarate and exercise on equine tendon healing: gross and histological aspects. J. Equine Vet. Sci. 21:335-340.

Alves A.L.G., Nicoletti J.L.M., Thomassian A., Hussni C.A. \& Watanabe M.J. 2002. Tendon splitting surgical treatment on experimental equine acute tendinitis. Arch. Vet. Sci. 7:45-51.

Barreira A.P.B., Alves A.L.G., Saito M.E., Amorim R.L., Kohayagawa A., Menarim B.C. \& Mota L.S. 2008. Autologous implant of bone marrow mononuclear cells as treatment of induced equine tendinitis. Intern. J. Appl. Res. Vet. Med. 6:46-54.

Batson E.L., Paramour R.J., Smith T.J., Birch H.L., Patterson-Kane J.C. \& Goodship A.E. 2003. Are the material properties and matrix composition of equine flexor and extensor tendons determined by their functions? Equine Vet. J. 35:314-318.

Buck C., Drommer W., Wagels R. \& Stadler P. 2002. Scanning electron microscopy examination of tendon biopsies in healthy horses and patients with different stages of tendon healing. Pferdeheilkunde 18:521-528.

Cherdchutham W., Becker C.K., Spek E.R., Voorhout W.F. \& Van Weeren P.R. 2001. Effects of exercise on the diameter of collagen fibrils in the central core and periphery of the superficial digital flexor tendon in foals. Am. J. Vet. Res. 62:1563-1570.

Crass J.R., Genovese R.L., Render J.A. \& Bellon E.M. 1992. Magnetic resonance, ultrasound and histopathologic correlation of acute and healing equine tendon injuries. Vet. Radiol. Ultrasound 33:206-216.

Dahlgren L.A., Nixon A.J. \& Brower-Toland B.D. 2001. Effects of $\beta$-aminopropionitrile on equine tendon metabolism in vitro and on effects of insulin-like growth factor-I on matrix production by equine tenocytes. Am. J. Vet. Res. 62:1557-1562.

Dahlgren L.A. 2007. Pathobiology of tendon and ligament injuries. Clin. Tech. Equine Pract. 6:168-173.

Denoix J.M. 1994. Diagnostic techniques for identification and documentation of tendon and ligament injuries. Vet. Clin. North Am., Equine Pract. 10:365-407.

Dowling B.A., Dart A.J., Hodgson D.R. \& Smith R.K.W. 2000. Superficial digital flexor tendonitis in the horse. Equine Vet. J. 32:369-378.

Dyson S. 1992. Ultrasonographic examination of metacarpal and metatarsal regions in the horse. Equine Vet. Educ. 4:139-144.

Fernandes M.A.L., Alves G.E.S. \& Souza J.C.A. 2003. Clinic, ultrasonographic and histopatological studies of two protocols of ultrasonic therapy on experimental tendonitis in horses. Arq. Bras. Med. Vet. Zootec. 55:2734.

Ferrari M., Weller R., Pfau T., Payne R.C. \& Wilson A.M. 2006. A comparison of three-dimensional ultrasound, two-dimensional ultrasound and dissections for determination of lesion volume in tendons. Ultrasound Med. Biol. 32:797-804.

Foland J.W., Trotter G.W., Powers B.E., Wrigley R.H. \& Smith F.W. 1992. Effect of sodium hyaluronate in collagenase-induced superficial digital flexor tendinitis in horses. Am. J. Vet. Res. 53:2371-2376.

Gaughan E.M., Nixon A.J., Krook L.P., Yeager A.E., Mann K.A., Mohammed H. \& Bartel D.L. 1991. Effects of sodium hyaluronate on tendon healing and adhesion formation in horses. Am. J. Vet. Res. 52:764-773.

Gaughan E.M., Gift L.J., De Bowes R.M., Basaraba R.M. \& Roush J. 1995. The influence of sequential intratendinous sodium hyaluronate on tendon healing in horses. Vet. Comp. Orthop. Traumatol. 8:40-45.

Genovese R.L., Rantanen N.W., Hauser M.L. \& Simpson B.S. 1986. Diagnostic ultrasonography of equine limbs. Vet. Clin. North Am., Equine Pract. 2:145-226.

Gillis C.L. 1997. Rehabilitation of tendon and ligament injuries. AAEP Proceedings. 43:306-309.

Gillis C.L. 2004. Soft tissue injuries: tendinitis and desmitis, p.412-432. In: Hinchcliff K.W., Kaneps A.J. \& Geor R.J. (Eds), Equine Sports Medicine and Surgery. W.B. Saunders, Philadelphia.

Goodship A.E. 1993. The pathophysiology of flexor tendon injury in the horse. Equine Vet. Educ. 5:23-29.

Goodship A.E., Birch H.L. \& Wilson A.M. 1994. The pathology and repair of tendon and ligament injury. Vet. Clin. North Am., Equine Pract. 10:323349.

Jann H. \& Stashak T.S. 2008. Tendon and Paratendon Lacerations, p.489508. In: Stashak T.S. \& Theoret C.L. (Eds), Equine Wound Management. Wiley-Blackwell, Ames.

Keg P.R., Van den Belt A.J., Merkens H.W., Barneveld A. \& Dik K.J. 1992. The effect of regional nerve blocks on the lameness caused by collagenase induced tendonitis in the midmetacarpal region of the horse: a study using gait analysis, and ultrasonography to determine tendon healing. Zentralbl. Veterinärmed. A. 39:349-364

Kraus-Hansen A.E., Fackelman G.E., Becker C., Williams R.M. \& Pipers F.S. 1992. Preliminary studies on the vascular anatomy of the equine superficial digital flexor tendon. Equine Vet. J. 24:46-51.

Machado M.V.M., Vulcano L.C., Hussni C.A. \& Alves A.L.G. 2000. Effects of laser therapy on experimental tendinitis in horses: ultrasonographic and histologic study. Arch. Vet. Sci. 5:111-115.

Maia L., Souza M.V., Ribeiro-Júnior J.I., Oliveira A.C., Alves G.E.S., Benjamin L.A., Silva Y.F.R.S., Zandim B.M. \& Moreira J.C.L. 2009. Platelet-rich plasma in the treatment of induced tendinopathy in horses: histologic evaluation. J. Equine Vet. Sci. 29:618-626.

Marr C.M., McMillan I., Boyd J.S., Wright N.G. \& Murray M. 1993. Ultrasonographic and histopathological findings in equine superficial digital flexor tendon injury. Equine Vet. J. 25:23-29.

Marxen S., Lacerda-Neto J.C., Moraes J.R.E., Ribeiro G. \& Queiroz-Neto A. 2003. Efficacy of Polysulphated Glycosaminoglycan in the intratendinous treatment of experimental equine tendinitis. Braz. J. Morphol. Sci. 20:43-46.

Marxen S., Lacerda-Neto J.C., Canola J.C., Moraes J.R.E. \& Ribeiro G. 2004. Intralesional polysulphated glycosaminoglycan as treatment of equine collagenase induced tendinitis: clinical, ultrasonographic and histopathologic evaluation. Arq. Bras. Med. Vet. Zootec. 56:701-708.

Oikawa M. \& Kasashima Y. 2002. The Japanese experience with tendonitis in racehorses. J. Equine Sci. 13:41-56.

Pasin M., Brass K.E., Rosauro A.C., Oliveira F.G., Figueiró G.M., Fialho S.S. \& Silva C.A.M. 2001. Ultrasonographic characterization of the flexor tendons in horses: metacarpal region. Arq. Fac. Vet. UFRGS 29:131138.

Patterson-Kane J.C., Wilson A.M., Firth E.C., Parry D.A.D. \& Goodship A.E. 1997. Comparison of collagen fibril populations in the superficial digital flexor tendons of exercised and no exercised Thoroughbreds. Equine Vet. J. 29:121-125.

Patterson-Kane J.C., Wilson A.M., Firth E.C., Parry D.A.D. \& Goodship A.E. 1998. Exercise-related alterations in crimp morphology in the central 
regions of superficial digital flexor tendons from young Thoroughbreds: a controlled study. Equine Vet. J. 30:61-64.

Rantanen N.W., Hauser M.L. \& Genovese R.L. 1985. Superficial digital flexor tendinitis; diagnosis using real-time ultrasound imaging. J. Equine Vet. Sci. 5:115-119.

Rantanen N.W. 2008. Muskuloskeletal ultrasonography. Compend. Equine 3:356-364.

Redding W.R., Booth L.C. \& Pool R.R. 1999. The effects of polysulphated glicosaminoglican on the healing of collagenase induced tendinitis. Vet. Comp. Orthop. Traumatol. 12:48-55.

Reef V.B. 1998. Equine Diagnostic Ultrasound. W.B, Saunders, Philadelphia. 560p.

Richardson L.E., Dudhia J., Clegg P.D. \& Smith R. 2007. Stem cells in veterinary medicine - attempts at regenerating equine tendon after injury. Trends Biotechnol. 25:409-416.

Silver I.A., Brown P.N., Goodship A.E., Lanyon L.E., McCullagh K.G., Perry G.C. \& Williams I.F. 1983. A clinical and experimental study of tendon injury, healing and treatment in the horse. Equine Vet. J. (Suppl.1):1-43.

Smith R.K., Jones R. \& Webbon P.M. 1994. The cross-sectional areas of normal equine digital flexor tendons determined ultrasonographically. Equine Vet. J. 26:460-465.

Spurlock G.H., Spurlock S.L. \& Parker G.A. 1989. Evaluation of Hylartil V therapy for induced tendonitis in the horse. J. Equine Vet. Sci. 9:242-246.

Thorpe C.T., Clegg P.D. \& Birch H.L. 2010. A review of tendon injury: why is the equine superficial digital tendon most at risk? Equine Vet. J. 42:174180.

Van Schie H.T.M., Bakker E.M., Jonker A.M. \& Van Weeren P.R. 2003. Computerized ultrasonographic tissue characterization of equine superficial digital flexor tendons by means of stability quantification of echo patterns in contiguous transverse ultrasonographic images. Am. J. Vet. Res. 64:366-375.

Watkins J.P. 1992. Tendon and ligament biology, p.910-924. In: Auer J.A. (Ed.), Equine Surgery. W.B. Saunders, Philadelphia.

Webbon P.M. 1977. A postmortem study of equine digital flexor tendons. Equine Vet. J. 9:61-67.

Webbon P.M. 1986. Preliminary study of tendon biopsy in the horse. Equine Vet. J. 18:383-387.

Williams I.F., McCullagh K.G., Goodship A.E. \& Silver I.A. 1984. Studies of the pathogenesis of equine tendonitis following collagenase injury. Res. Vet. Sci. 36:326-338.

Yamada A.L.M., Alves A.L.G., Hussni C.A., Nicoletti J.L.M., Thomassian A., Watanabe M.J. \& Carneiro R. 2009. Comparison of different doses of collagenase-induced equine tendonitis: clinical and ultrasonographic study. Ciência Rural 39:1124-1130.

Yamasaki H., Goto M., Yoshihara T., Sekiguchi M., Konno K., Momoi Y. \& Iwasaki T. 2001. Exercise-induced superficial digital flexor tendon hyperthermia and the effect of cooling sheets on Thoroughbreds. J. Equine Sci. 12:85-91. 